\title{
INTRODUCTION: VIOLENCE:
}

\section{AND POSTMODERNITY}

Within the general conversations on violence today, including those of postmodern deconstruction, feminism, poststructuralism, and various others, Ricoeur's essay, "Language and Violence," takes the most general perspective possible, including within its sweep all the essays of this volume. For, in recent philosophical discourses on violence, the scope of consideration often extends even to texts within a view of signs, and is not limited to interpersonal relations of one will in relation to another. And Ricoeur's article extends even beyond this to violence in nature, thus setting the stage for all of the treatises in this volume. This article also shows the importance of the confrontation between language and violence as underlying all human problems. It thus takes on a special importance for us in that it address the broadest extension of violence between two extremes: the violence of nature, as in hurricanes; and human violence as in the case of murder. Most of the essays in this volume deal with human violence of one form or another rather than the violence of nature, thus leaving Ricoeur's in a unique place in breadth. Ricoeur brings these two together in the realm of the intermediate, human violence. This latter is inclusive of the violence of nature within human being, and stretches the interrelation in delving into the ramifications in the relation between language and violence. Ricoeur, thus, considers violence external to us, then, the nature internalized that overwhelms us, and finally the violence of one will against another. It is in this context that violence and language are seen as opposites. And Ricoeur interprets the opposition between language and violence to be between coherent discourse and violence, but a coherent discourse not possessed by anyone specific, for that would be a fraudulent discourse, one that attempts to make a philosophical particularity prevail. And falsified words make language the voice of violence; violence speaks. "That which speaks, in relation to the meaning, is 
violence" [35]. For Ricoeur, such violence of language arises not from language as code or from the anatomy of language, but, rather, from language as discourse. The code is innocent, since it does not speak. Rather, only discourse speaks. Thus, in contrast to postmodem deconstruction's reduction of language, Ricoeur does not consider violence to be linked to language as code, but, rather, to discourse. He explicitly and clearly distinguishes words in speech from the signs in dictionaries, which are not yet words, but merely signs delineated by other signs in the code. But they take on meaning only in the moment of discourse of a sentence. This is the field of the confrontation between violence and language, and not as later postmodern deconstruction would have it, between the code and violence. And, in the three spheres of politics, poetry, and philosophy, it is the word that is the focus of violence and meaning in discourse.

In the context of political violence, Ricoeur highlights the role of discourse in seduction, persuasion, and flattery, showing in this context the preference for the sophist to that of the executioner. But the violence of tyranny and revolutions does not exhaust violence of politics, since politics exists because the city rests on the overcoming of private violence brought to the submission to a rule of law. "The words of the city bear this universal mark, which is a kind of non-violence" [37]. And this rule of law is a sort of power or violence that works through private violence to speak to language of value and honor, allowing the common will to conquer our wills.

And even the most innocent of language, that of the poet, does not escape the tension of meaning and violent particularity. The poet, in giving himself up to meaning, in letting be, is where language is least at our disposition, and thus is a non-violence of discourse. Yet it is precisely here that the violence of particularity arises. Bringing Being to the word or to meaning is a capture of Being in the word, thus showing the appearance of the violent man at the point where being and meaning unfold. "The poet is the violent man who forces things to speak. It is poetic abduction" [38].

And the third realm of the tension of violence and language is that of philosophy, understood as the "desire for meaning, by the 
choice in favor of coherent discourse", by an option for "order and coherence"[38-39]. With this understanding, as will be seen in some of the later articles, Ricoeur supplies a context for dialogue with postmodern deconstruction and its will to believe in logos and the priority of the negativity latent within that option. There are two contexts of violence in philosophical language: first, in the violence of the point of departure or a beginning as an exercise of force; then there is the violence of a particularity, a failure to recover totally one's presuppositions; and finally, the violence of premature conclusion, in that the process of totalization, which can never be closed, is arbitrarily terminated in, for instance, a written account or book.

Ricoeur presents three rational conclusions around the notion of rational meaning or discourse that underlies all of his reflection here. The first is the goal of language that must obtain if this reflection is to make sense, giving violence an opposite. Ricoeur is here thinking not of an exterior finality imposed from without, but of the Aristotelian context of the full manifestation of language, somewhat in the sense of Humboldt's view of the "genesis of language as the complete manifestation of the mind, as its self-manifestation, its unfolding in plenitude" [39]. This view of language as a call to express the thinkable makes possible the dialectic of this article. Second, in this theoretical context of rational meaning, understanding cannot be reduced to calculation or to instrumental intelligence. Any such reduction of reason to understanding ends inevitably in violence. And finally, in this theoretical context, when calculative intelligence takes hold of language, it "produces the same effects of nonsense" [39]. In this context of calculation, knowing the structure of language, or, Ricoeur might add today, to know the process of the structural relations, "does not advance one a step in rational meaning. For what is questioned is the meaning of discourse, not the structure of the keyboard on which it plays....Instrumental intelligence and senseless existence are the twin orphans of the death of meaning" [39]. Ricoeur now turns to practical conclusions.

Ricoeur offers a few simple rules for living the intermediary role between language and violence. He contends that we must recognize the fundamental opposition between language and 
violence as the precondition for recognizing violence where it appears and for having recourse to it when necessary. And such a recourse to violence is always a "limited culpability," a calculated fault; he who calls a crime a crime is already on the road to meaning and salvation" [40]. Further, it is necessary to bear witness to this formal truth of the non-violence of discourse as an imperative; "Thou shalt not kill," recognizing the other as a rational being to be honored. And the pressure from such a morality of conviction on the morality of responsibility leads, for instance in war, not doing anything that would prevent peace. And the unique role of the non-violent person is to testify to all the goals of history and of violence. And if such non-violence belongs to the ethics of conviction, it can never take the place of the morality of responsibility. Here, in this essay, over thirty years ago, we already see the explicit dialectic between the ethics of conviction, leading to teleological ethics, and to a deontological ethics of responsibility, the latter of which leads back to a second naivete regarding an ethics in the concrete situation of conviction.

Ricoeur ends this essay with another rule, that of the non-violent practice of discourse itself. While no claim is made in favor of one mode of discourse, it, rather, respects the plurality and diversity of languages, leaving the modes of discourse in their proper place. "Respect for the multiplicity, diversity, and hierarchy of languages is the only way for men to work towards rational meaning." [40].

Although he does not dwell on it, Ricoeur has opened the discourse to violence in nature and in the human situation that we perpetrate against one another, thus opening the door for the discussion with the postmodem deconstructionists, for whom violence does not support the centrality of the human in a humanism. This we shall now see as our context for beginning this volume. We now turn to the second article in this collection: "Taming Violence: Ricoeur and Derrida," which relates Ricoeur's thinking to the recent broad context of violence in postmodemity.

Discussions of violence have recently taken a central role in postmodern conversations of philosophy/nonphilosophy. According to the usual script of deconstruction, the violence of philosophy and of ontology and, indeed, of logos in general and of 
all meaning formation is a power play that must be subverted by the deconstructive process. Within this general postmodern conversation, Paul Ricoeur, in his own way, addresses the phenomena that deconstruction indicates as violent, taking them in a more positive way. In spite of this fundamental difference, Ricoeur considers violence and language as contraries to "occupy the totality of the human field" [32].

Within this broad context, this article focuses first on postmodem deconstruction's opposition to the violence of philosophy and logocentrism; then on the very violence latent within the deconstructive process, beginning with that in relation to a basic will to believe, contrasting this interpretation of violence with the surplus of meaning considered not as violence, but rather as an attempt to render account of an excess or fullness of sense. Second, the violence within deconstruction's diacritical view of language and within its view of the living present is considered, clarifying the fundamental nature of the violence of deconstruction. Then, the role of violence in Ricoeur's philosophy is considered in relation to the surplus of meaning, the living present, and language taken as discourse. Thus, the thesis of this article contends that deconstruction misinterprets the relation between violence and language due to its view of the living present and sign, and that, with a revision in this view of language (sign, word, and discourse) and the living present, the dialectic between violence and language can be reread and replaced in a context that makes sense out of making sense.

Instead of considering violence to be intrinsic to sense, to the living present, to presence and to anything established, it is possible, according to this article, to see the violence intrinsic to the very deconstructive process itself, to clotural reading, in its priority given to the closures of sense, time, sign, presence: i.e. in the view that anything that is produced by the flux other then the undecidable is violent. Thus, we can see that violence is intrinsic to the whole deconstructive process at a basic level. In contrast to deconstruction, Ricoeur's priorities do allow for saying something to someone and for a viable semantic and ethical framework for reflection today.

Gary Herbert, in the article "The Anatomy of Rights-Based 
Violence," shows in an extremely clear and precise way that the logic of natural rights easily and inevitably leads to the conceptual legitimization of violence, so that the conceptual culprit of much modern violence is the western liberal-rights tradition itself. And, in its more subtle forms, this emphasis on individual rights and liberties manifests itself in the defense of privileges and in various forms of nonrecognition. The conclusion drawn by the critics of the liberal-rights tradition is that there can be no solution to the problems of violence that does not penetrate to, and modify or reform these deeper conceptual substructures, so that what obtains is a "coexistent freedom," where the satisfaction of one person's rights does not have to come at the expense of another person's rights. "It is to promote a system of rights in which, in the words of Maurice Merleau-Ponty, 'the recognition of man by man' becomes a moral priority"[60].

Herbert shows clearly how the recognition of individual rights is considered the metaphysical a priori of all moral and political judgment, and all who resist this are dismissed as irrational. Herbert sees Merleau-Ponty's positing of "the recognition of man by man" as required for transcending the classical rights-based legitimization of violence. It is Herbert's suggestion that the revolutionary recommendations for change by these critics of political-liberalism only point the way to transformation of violence, easily issuing in "new forms of violence that are often conceptually invisible to those who argue for them," remaining nevertheless within the liberal-rights theory and thus "subject to versions of the same critique." This becomes clear in tracing out the evolution of rights theory and violence in it.

Herbert traces the emergence of the idea of individual rights from Thomas Hobbes' view of the human natural condition, showing its expression as the survival impulse in relation to the restless desire for power that serves this impulse. This condition is not one of evil or intrinsic violence, but rather one in which it is reasonable for humans to have recourse to violence. According to Hobbes, we have a right to whatever measures we deem necessary to insure our survival, security and wellbeing, even though we could be wrong in this assessment. This is limited only by the power of our own imagination, since it exposes potential 
threats and justifiable responses as justifiable violence. "Unmediated natural rights (those rights one must defend by himself) becomes a recipe for and justification of unlimited violence whenever and wherever there is no sovereign authority, and one finds himself in a situation where he must serve as the sole guarantor of his own security" [65]. Unmediated rights leads to unending violence, with each attempting to protect him/herself from real or imagined threats, thus themselves becoming a threat to another. Thus the state of nature is one of unending violence. The posed solution comes by way of invoking an irresistible power, a sovereign with absolute power that could be a guarantee against being subject to violence. The sovereign power serves as a threat allowing subjects to know with certainty they are safe, since no one would willingly bring down the power of the sovereign upon himself for such acts. Herbert says: "The problem for subsequent philosophers in the liberal-rights tradition was to save us from such solutions, i.e., from rights based abuse of sovereign authority. What was needed was another more sociable way of conceiving the mediation of rights that simultaneously (1) avoided the reasonableness of violence and (2) escaped the need for submission to a sovereign with absolute power," with the latter possibly leading to rights-based abuse of sovereign authority.

Locke adds to Hobbes' concept of rights a reflexivity that entails a natural ownership of investing his labor in things. "One owns all his own possessions and his own self as well. One's life is one's property" [68]. By considering the labor of consciousness exercised on himself the source of acknowledging one's actions as one's own, and thus making the person the sole property of oneself, Locke generates the foundations of natural responsibility in producing the foundations of natural rights. Locke considers rights to precede and preexist all obligations, thus agreeing with Hobbes regarding the unilateral character of rights.

Herbert indicates that the philosophical corrective and critique of such rights-inspired violence comes from Immanuel Kant and Gottlieb Fichte. They viewed the natural condition to be one of no rights, since none are recognized, thus abandoning the unilateral character of rights. Rights exist only where there is the corresponding obligations to respect these rights. Since such a 
view does not supposedly allow rights to clash, acts of violence would be out of the question. Along this line, Herbert indicates that Kant defined a right as "the capacity for putting others under obligation," thus making one's own right depend on the other's capacity to be obligated, which can only obtain if the other is free or autonomous, able to impute onc's own actions to oneself, and thus be a person. Herbert quotes an important text of Kant to show the connection among rights, freedom and obligation: "We know our own freedom (from which all moral laws and so all rights as well as duties proceed) only through the moral imperative which is a proposition commanding duty, from which the capacity for putting others under obligation, that is, the concept of a right, can afterward be explicated." [Metaphysics of Morals, 64] Only another free person can invoke obligation. And it is sufficient that mutual recognition of right be provided for without relying on the morality of man's inner motives, which can hardly be absolutely pure for humans, but simply by insisting on the external conformity of his will to the law. Thus, each perceives the other externally as an independent will whose actions can be imputed to him or her. Thus, one's capacity to obligate another and one's rights depend on one's capacity to reveal oneself to the other as a free being, one who imputes his actions to himself. Further, all rights are dependent "upon the reciprocally sustaining external relationship of will to will in which each extemally recognizes (or acknowledges) the other as internally free" [72].

In a similar vein, Fichte says one must manifest free activity by restricting oneself, by respecting the other's property, thus revealing oneself as an autonomous being, a person, one capable of being obligated. And the other, only by reciprocating, can obligate one as well. The failure of this leads to reestablishment of the conditions of mutual violence, leading Kant to affirm that the only original right belonging to every man in virtue of his/her humanity is freedom "insofar as it can coexist with the freedom of every other in accordance with the universal law" [H, 73, Kant, $\mathrm{MM}, 63$ ]. By following the law of always treating the others as free beings and not as mere things, each becomes a lawful member of the community and yet remains completely free.

It can be seen that such a conception of rights in which rights 
and obligations are correlative does not overcome the problem of rights-based violence if mutual recognition is not assured. Kant espouses a "law of reciprocal coercion," that is "necessarily in accord with the freedom of everyone under the principle of universal freedom" [MM, 58]. Herbert contends that, for Kant, we are free because we have authorized each other's possessions and the existence of a sovereign power to guarantee those possessions. And punishment for the violation of one's rights must take the form of retribution, not at all looked upon as violence by Kant. In fact, it is a repudiation of violence, in that it, and it alone, is the recognition and respect for the dignity of each as free and responsible.

The contemporary view of rights has supplanted them from the Kantian concem for moral autonomy, no longer requiring self-ownership and individual autonomy for human dignity. This move does allow the extension of idea of rights to the senile and otherwise mentally impaired, to fetuses, etc., overcoming certain violence in our society. Herbert shows that the contemporary loss of individual autonomy of the will and dignity has diverted attention to human needs, so that now, human dignity is measured by the material conditions of one's life. Those with lack in this area have then been denied basic human dignity, a condition formed upon people by the competitive structures of industrialized society, and hence victimized by a subtle violence committed upon them. And the Kantian demand that people "assert the right of humanity in their own persons" [76] easily becomes the justification of a naked demand for satisfaction and recognition, with nothing to limit the demand or give it meaning other than the demand itself, augmented, perhaps, by the individual's personal assessment of the material conditions of life he or she needs to have met in order to enjoy basic human dignity. This leads in many directions, including the conclusion of being wronged simply because someone else has more, or has accomplished more and thus appears to be worth more. Herbert sees herein the danger of a retum to the immediacy of Hobbesian natural right and of the conceptual content of those structures condemned for their legitimation of structural violence. Thus, under the guise of overcoming structural violence, we see a return 
to another structural violence, as Herbert shows, with the concept of human rights as a conceptual enabler, untempered by considerations of personal responsibility. He goes on to show that the "act by which one asserts the right of humanity in his own person is logically indistinguishable from the act by which one does violence to another. The structures of violence have not been escaped" [80]. He sees that perhaps a return to Kantian-Fichtean idea of personal responsibility or to some Hobbesian notion of political authority is needed in order to reconcile a system of rights with a coexistent freedom and peace.

M.C. Dillon's paper, "Reversibility and Ethics: The Question of Violence," continuing the themes of human violence and violence in relation to language, argues against two theoretical standpoints. The first contends that all human action entails violence. The second contends that discourse, the traditional alternative to violent confrontation, is itself necessarily violent. Dillon contends that the conjunction of these two obscures significant differences between violent and non-violent human behavior and, thereby, atrophies a legitimate moral animus against violence. The standpoint he defends rests on the assertion that humans are capable of direct perceptual experience of the pain of other humans, that this experience is the ground phenomenon of morality, and that it allows us in principle to adjudicate between violent and non-violent action, to distinguish among kinds and degrees of violence, and to assess evidence bearing on questions of vindication and culpability.

This essay begins with an important limitation of violence to the human sphere of forceful imposition of human will, thus removing it from the broader conversation of violence inclusive of natural violence, which itself, as seen above, can be seen in humans.

Dillon points out that the "political standpoint he [Merleau-Ponty] attributes to Marxism is challenged by the ethical implications of the thesis of reversibility he developed in his later writings"[85]. Dillon goes on to consider this view that violence is unavoidable, and that it is a matter of choosing our violence. He contrasts this radical view that eliminates the pacifist altemative with the equally radical view that the non violent 
alternative must always be sought. One always available alternative to violent action is rational discourse, for instance, in the peace process during a violent war. If, however, discourse itself is considered a form of violence, then again violence is unavoidable. And this is the argument supporting semiological reductionism. "The violence of signifiers is inescapable because all experience is mediated by signifiers and is meaningless without them." To perceive a thing is to violate the ipseity of the thing, since we are barred from the signified [88].

According to semiological reduction, language is always violent, as is human action, always violating the others' propriety. And here it becomes difficult to distinguish types of violence. Dillon gives an intriguing account of semiological reductionism in its view that the signified can never be present, even to the witnesses or victims themselves, and therefore "violence atrophies as a measure of moral judgment" [91]. Dillon sees the mistake of semiological reductionism to lie in the inference that the "significance of all persons, places, and events is exclusively determined by the cultural forms or signifiers that inform our experience of them. ... meaning derives exclusively from signifiers" [92]. Thus, this position demands that meaning is ideal. "This premises has the effect of ruling out the possibility that the persons, place, and events, themselves, play a crucial role in the formation and application of immanent forms or signifiers" [9192]. And, of course, Dillon holds the contrary.

Dillon holds that we do have access, for judgment, to others in the context of the ethics of reversibility, where "I am capable of direct experience of another - where I can directly perceive the intentions of others in their bodily comportment, where it is possible for me to sense the sense of another's sensing of me that the perceptual experience provides an evidential basis for judgments I may make about it" [92]. And evidence is accessible to third parties, so that at least fallible but non-arbitrary judgments can be made. And it is in this domain of discernment and judgment that the radical positions making violence absolute fail, in spite of a positive element of each: Marxism reminding us that every action has a political dimension; and deconstruction in "demonstrating the pervasive and insidious effects of systems of 
signifiers operating beneath the level of deliberation and awareness" [94].

For Dillon, violence is always bad, but is sometimes justified, so that therefore there can be good fights and just wars. These, however, are to be avoided except as a last recourse. There is no purity. Yet, violence as such cannot necessarily and in every case be condemned. Mediation is preferable to any violence, and truth is its ultimate ground, commanding assent even from differing parties. And although discourse can be violent, it is not originary violence, but, rather, even as fallible, is our main recourse against violence.

In the final analysis, 'the question of violence is finally a question of love-hate-indifference,", a thought that according to Dillon, has guided this essay all along its way. "Nobility, acting in accordance with one's highest ideals, ideals founded ultimately on the pathos of reversibility, is the locus of the criteria by which to judge violence" [100]. This nobility is the attempt to render the Greek word, "Kalon," and, as such, is the basis for judging everything, including violence.

In his article, "'An Ethics of Violence Justifying Itself." Sartre's Explorations of Violence and Oppression," Robert Bernasconi stresses the continuities in Sartre's various reflections on violence, emphasizing the strands of the Notebooks for an Ethics that anticipate and shed light on the later and more familiar accounts. He does this, however, without implying that Sartre held a single view across this period. Bemasconi's reflection traces the contours of Sartre's profound insight and recognition of the "depth of the violence inherent in society" [117]. He points out that Sartre's various discussions of violence manifest a sense of exploration, and hence should be read as provocations to think further rather than as dogmas - a manner of reading that we will see in the articles by Mui and Flynn, and one that Bemasconi expertly sets into motion.

In his Notebooks for an Ethics Sartre lists principles in an attempt to expose justifications of violence, while, in the same work, he tries to show the revolutionary possibilities of violence in invoking the same principles. He sanctions the use of violence by the left, which itself has had violence done to it. And, even 
further, Sartre seems to agree with the Maoists in that revolutionary violence born among the masses is considered to be moral. Bemasconi's thesis contends that such comments not only must be seen in the context of their times, but also must be assessed "in the broader context of Sartre's reflections on violence, particularly in that most exploratory of books, Notebooks for an Ethics" [117].

This article draws a wealth of insight from the manner in which Sartre interrelates violence, oppression, revolution and law, with violence and oppression more explicitly interrelated and distinguished. Violence can only be considered in relation to laws that it violates, while oppression can be institutional, and thus is legitimated by law, giving sanction to the oppressing class at the expense of the oppressed class. These conditions obtain for the society with slaves, for the bourgeois society of capitalism, as well as in the United States society with the condition of the blacks. This is an illustration of the insight that violence always attempts to legitimate itself, leading to institutional forms of violence. And it becomes part of the legitimating of the violence against such institutions "to disclose the violence that created and sustained" such institutions [107]. The "rights" of the oppressors is legitimated by law, making it unlawful for the oppressed to change the conditions of oppression, thus revealing, for Sartre, the connection between right and violence. And violence is the condition for a new order to be initiated. The true revolutionary does not claim such rights, but rather, attempts to destroy the "idea of rights which they understand as a hoax of the privileged class" [109]. The oppression and the right it sanctions must be destroyed.

Bernasconi goes on to show that in the Critique of Dialectical Reason, the emphasis moves from the act to the conditions of violence, focusing on violence as scarcity, and thus resolving the negative in history. Sartre aims in this work is to appeal to history rather than to economic or sociological interpretation, emphasizing free praxis over determinism. This dynamics can be applied to the violence in colonization. "Past oppressive praxis produced the situation" [114]. This essay takes into account the ramifications of violence to the colonized, the complicity of the 
oppressed, and the necessity of violence for the colonized, which results from the prior violence of the colonizers.

These are the contours of a discourse on the ethics of violence justifying itself.

The article by Constance Mui, "Rethinking the Pornography Debate: Some Ontological Considerations," in a creative and clear application of Sartre's philosophy, reveals the subtle violence done to women in certain expressions of pornography. In this treatment, Mui opens a new dialogue in feminist scholarship on pornography by exploring the possibility of posing a different set of questions than those posed in the debate over censorship and pornography, thus situating the debate in a more constructive philosophical framework. The article accomplishes this by focusing the debate on gender issues surrounding an ontological study of the body. Even for feminists and academics who respect freedom of expression, there is something deeply disturbing about the pornographic portrayal of women, one so offensive that it challenges even otherwise liberal sensibility. Mui rearticulates in lucid terms precisely what it is here that is found so disturbing. She does this by reframing this debate in a different philosophical construct that raises serious questions concerning authentic human existence, that of Jean-Paul Sartre's ontology of the body, his theory of intersubjectivity, and especially emphasizing "the look" and the ontological categories of freedom and objectification.

In her exposition, Mui shows the place of human freedom in Sartre's ontology of human existence as forming the comerstone of his theory of embodiment. To exist as freedom, humans disobey the principle of identity, do not have fixed identity, and project existence beyond their past toward some future possibility, thus, in this process, pulling away from any identity that our past might have conferred upon us. This, for Sartre, is ontological freedom, providing a fundamental conception of person that allows us to speak meaningfully of concrete freedom in terms of such issues as choice and oppression. These points lead to a very insightful presentation of the body.

How can an embodied person exist as freedom? Mui presents Sartre's distinction of three ontological dimensions of the body: Body as Being-for-itself or body-as-subject [I am my body], 
body-as-object, and, finally, body-for-others, which, in the traditional interpretation, nuns the risk of challenging the unity of the lived body or the body-for-itself. Thus, the body-for-others is tied to Sartre's development of "the look," which makes one aware of her/his body-as-object. In the look the Other is presented to me as a conscious subject capable of turning me into an object. As such, because of the look, the other must be a conscious subject with freedom.

It is in this light from Sartre's ontology that Mui now takes up the problem of pornography, reconstituting women's oppression in these ontological terms, showing how women, within a culture of "the look" - women-watching - suffer not merely a loss of dignity, but of being. To quote Mui, "'The look' affirms the freedom of the looker as subject at the expense of the freedom looked-at, the person gazed upon."[125] And "the look" in pornography, produced for the heterosexual male voyeur, following the same analysis, is drastically worse. The object of the voyeur's gaze makes her exist in a structure that reduces her whole being to an "inert body that is solicited, probed, scrutinized, and appropriated by a gazer." In this case, the woman in pornography does not exist her body, she exists as a very impersonal body, thus especially betraying the subjectivity of woman. Since the woman here is not ever a particular subject, pornography objectifies, not a woman, but rather, the idea of woman, and thus all women, who suffer a loss of being. Surprisingly, Mui admits that her argument does not imply that all pormography is necessarily inauthentic, but rather issues a challenge to anti-censorship feminists who are interested in working toward a feminist "re-vision" of pornography. It is ultimately a challenge as to whether or not "it is possible to secure people's status as free subjects within the context of 'the look'." [128]

Thomas Flynn's article, "Sartre on Violence, Foucault on Power - A Diagnostic," focuses on violence in the work of Jean-Paul Sartre beginning with the Preface to Frantz Fanon's The Wretched of the Earth, the terminus ad quem of an "evolution in a philosophical theory of violence that had occupied Sartre for some time and which, it seems clear to me, he never resolved to 
his satisfaction" [129]. For Sartre, fratemity and violence are two aspects of the social bond that he has not succeeded in reconciling. Flynn proposes to consider the terminus a quo of this theory from one of the earlier discussion of Sartre. He then turns to Foucault's treatment of violence and power, in order to ground some comparison and contrasts between Sartre and Foucault. Flynn is attempting to cast light on the question of the possibility and limit of dialogue diagnostic as illuminating a discourse and practice between existentialist and post-structuralist philosophies in general. He shows throughout this article that violence is an abiding concern of Sartre, especially in the second half of his career, yet as early as the composition of the Notebooks we find him "coming to terms with the challenge of trying to reconcile the inevitable violence of our interpersonal and social lives with the full freedom of the existentialist individual that he had championed in Being and Nothingness" [142].

Since Flynn considers Sartre to be always an ontologist, a philosopher of the imagination, and a moralist, he treats Sartre's "mini treatise" on violence in the Notebooks along those lines. First, it is necessary to mention that whatever Sartre develops as a view of violence springs from the fundamental ontological distinctions of Being and Nothingness, since, in violence the freedom of the other is treated as a thing even in recognizing its nature as free, thus rendering it captive and free, or captive insofar as it is free. [This admission agrees with the analysis of Mui.] Flynn instructively quotes Sartre's text" "the impossible ideal of violence is to constrain the other's freedom to choose freely what I want...the lie is closer to the ideal of violence than [is] that of force," here reminding us of Ricoeur's view of the propagandist in the violence of the political, who persuades and seduces as modes of violence, rather than employing sheer tyrannical force. Flynn goes on with the quote and his analysis to point out the psychological element added by Sartre, i.e., the lie that hides the victim's freedom-refusal in the liar's bad faith, a psychological element that Foucault will be seen to avoid.

Sartre, in a sense, sets himself off form others to some extent, in that nonvoluntary violence would not be an entirely meaningful notion, as also becomes clear in the later distinction between 
physical and moral violence. This is a restricted use of the sense of violence, but he is consistent in this. In turning to the imaginary and violence, we must realize the centrality for Sartre for such a consideration, since the imagination is already central to his ontology, seen above. It is the imagination that allows us to "derealize" perceptual objects and thus to consider possibility, negativity and lack, as well as to deceive. Flynn interestingly observes, getting to the core of the role of the imagination here, Although not all uses of the imaginary entail violence, it seems to me that most, if not all, cases of Sartrean violence employ the imaginary. And it is the act of lying that is for Sartre the model of violence, for the lie transforms man into a thing. But at the same time it wants to keep him free, at least in most cases" (NE 198) [133]. Flynn considers the lie as a compendium of the element of Sartrean violence, summarizing it around five aspects characteristic of both.

Violence, like the lie, shows an option for the inertia and passivity of the victim as thing, exploiting the ambiguity of the in-itself/for-itself ontology of human reality, inheriting at once its ultimate failure. Secondly, the lie and violence entail a negation of time by sheer power of will as refusing being-in-the-world in favor of an immediacy as "timeless" time of nature, of things: first by appeal to analytic necessity, carrying over into the realm of identity and essence, as a refusal; and second, by the denial or refusal of world, thus negating temporality. Flynn brings up a couple of points here that are important for this volume, as well as for the issue of violence in Sartre: "Although Sartre is phenomenologically astute in observing the implicit collapse of temporal spread of lived time into the atemporal instant, he overlooks one of the most prevalent forms of violence, namely that which infests the future by means of threat." First, relevant to Sartre view and to Flynn's critique, threat is a violence, not considered by Sartre, that does indeed entail the future in violence; but, second, in indicating Sartre's astuteness regarding the temporal spread of lived time in relation to the atemporal instant, Flynn serves to show, as arises in other articles contributed to this volume, a place of focus in relation to a loss by postmodern deconstruction, that is, as will be seen, the loss of the 
lived for the abstract in Derrida's critique of Husserl, a failure that is not irrelevant to the question of violence, as becomes explicit in the article considered above: "Taming Violence: Ricoeur and Derrida."

The third element of the lie in violence is that of destruction or the nihilating power of consciousness acting, in violence, through the imagination. And fourth, as with the lie, the violent person lives in bad faith due to the counting on the richness of the world to support his destructions and to provide new things to be destroyed. And, finally, like the lic, violence is a self-defeating behavior (conduit d'échec) as a way of "evading the harsh demands of praxis and the real" [137]. We can now turn to violence and the moral.

At the heart of this consideration of violence and the moral, Flynn notes Sartre's speaking of an "ethic of violence" "just as he sometimes refers to a "bourgeois ethic." It is clear that the ethical properly speaking, that set of relationships between free agents mutually respecting and fostering one another's freedom - that this ideal, at least in our present socioeconomic condition, is simply that." He mentions that Sartre in the Critique focusing on the quasi transcendental role of scarcity that ends up in warring camp, and the consequent description of violence as interiorized scarcity. Flynn proceeds to treat three ethical concepts from the Notebooks that entail violence: the spirit of seriousness; the ethics of rights and duties; and bad faith.

The spirit of seriousness reflects the familiar inauthentic attitude of the moral absolutist that Sartre so adamantly opposes as the antithesis of moral creativity, thus constituting a form of violence in positing values at the expense of Sartrean authentic freedom. Similarly, the ethic of rights and duties arising out of the enlightenment tradition entails an acontextual ethic of obligations and demands driving toward unity and uniformity, thus constituting a violence to the singularity and uniqueness of the concrete person and situation. This rendition of violence reveals the latent violence of such a Kantian orientation that is not brought back to the earth of the singularity of the situation of particular judgment in situation. Flynn goes on to show that "If 'demand' is violent in its insensitivity to the unique situation of 
each agent, 'appeal' is the bond among freedoms that respects the individual in his or her singularity. In fact, the gift-appeal relationship emerges from the Notebooks as the model for the non-alienating reciprocity that authentic morality requires" [140] And, finally, regarding bad faith, Flynn begins by disagreeing with Sartre himself concerming the ethical import of bad faith, showing the distinctive disvalue in the term. The violence of bad faith is entailed in having another in me, as I am an other and this other is not me, in the form of my obligation, in which 1 deliberately conceal from myself that I am the source of this obligation. Of the many forms of violence considered in this context, it can be seen that they entail any constraint on my consciousness-freedom imposed by another freedom contrary to my willing it, even if it is from my own freedom as other. And it is worth mentioning the three types of violence that Sartre insists upon: Offensive, Defensive, and Counter violence. Now Flynn turns to Foucault on power/violence.

Flynn notes the obvious opposition between Sartre and Foucault in the latter's rejection of philosophies of consciousness and subjectivity along with totalizing thought in favor of impersonal rules and systems, and in his linguistic turn. He then notes three theses about Foucault's use of "power" in the attempt to focus on his understanding of violence, leading to a comparison and contrast with that of Sartre. These theses focus on the term "power" as a set of strategic relations between individuals or groups, as relations of struggle and resistance; his analyses of these is impersonal as befits such a philosophical analysis. And these power struggles, though impersonal, are between individuals and groups, falling into line with his view that power denotes "action on the action of others" [145] And Foucault comes close to Sartre in insisting on the need to identify the agents responsible for social domination. Thus, it is seen that, rather than Sartre's primacy of individual praxis in social causation, Foucault uncovers the "mechanisms of power" as the techniques and procedures that serve the interest of the bourgeoisie at a certain time. And it is the notion of power in Foucault that must be seen in relation to violence, before a comparison and contrast are possible with Sartre. 
Power acts not directly on others, but rather on the actions of others. In itself the exercise of power is not violence, nor a consent, but rather is a "way of acting upon the acting subject or acting subjects by virtue of their acting or being capable of action [147]. This point leads to the comparison between Sartre and Foucault on the basic interplay of power and freedom in Foucault's analysis. Flynn shows how Foucault speaks less of essential freedom, as does Sartre, but rather of an agonism "of a relationship which is at the same time reciprocal incitation and struggle; less of a face-to-face confrontation which paralyzes both sides than a permanent provocation" [148].

Flynn's discussion of Sartre and Foucault to this point has aimed at the diagnostic at the end, in which he compares and contrast explicitly the two views of violence. The first point of agreement between them is that violence can take place only between free individuals or groups, thus allowing the experience of freedom to be a starting point for such comparison and contrast. Yet, Flynn indicates three points of sharp contrast: first, their model of social intelligibility; second the means of analysis, and third, the goal of emancipation from violence.

Flynn suggest that perhaps the only space for fruitful dialogue between these two thinkers is freedom, for each of whom this is central. He goes on to show the problematic dimension of each thinker regarding freedom and violence, leading to impossibilities within the doctrine of each, and concluding that this may be their legacy to our post-modern situation, the possibility of the impossibility of their respective impossibilities. Thus is revealed explicitly the deconstructive process operative in this fine article, and its place in this volume.

Richard Cohen begins, in his article, "Levinas: just War or Just war: Preface to Totality and Infinity," with the fact that the worst form of violence is war. This focus is central to the short preface to Totality and Infinity, written after, and continuous with, its concluding section on the ethical relation of the face-to-face "between I and other where both terms retain their independence by relating across moral and juridical demands, he characterizes the pluralism of the ethical relation as alone making peace possible" [153-154]. This article shows how this is the case. The 
discussion of peace at the end of this work is, as a function of the plurality of persons made possible by ethics, the context for the preface on war, thus constituting, in a way, a working from war to peace.

War, for Levinas, suspends and makes a mockery of morality, holding in abeyance the command not to murder emanating from the ethical proximity of the face to face, commanding not to murder, and conjuring forth the responsibility and obligation for the other in its transcendent alterity. Thus, War, then, as this suspension, is worse than the opposite of morality, as evil is the opposite of good. "...war exceeds opposition by totalization the elimination of otherness. War is the mockery of the entire ethical schematism. This schematism: (1) "absolute good orienting from above, manifest through the transcending moral height of the other, the other's absolute priority over the self; (2) Good versus evil, the other as needy; (3) "absolute evil below, killing, war, the suspension of morality. For Levinas, the ethical self becomes an insatiable desire for the most desirable as the "good beyond being," once this self is charged by the transcendence of the face to face. And concrete ethical life takes place within this schema, judging goods and evils as closer or farther from that pure, orienting good. War is a mockery of this whole schematism. As absolute good makes the ethical realm possible, war renders the same realm extra - moral, "turning it into an amoral play of forces, interactions whose significance comes without reference to good and evil". War then becomes absolute violence, "violence absolutized, force against force" [158]

And if war is the ultimate ground for signification, then to be sincerely moral is to be duped by morality, a view with which Levinas and Cohen do not agree. Thus is revealed the context for Levinas's initial question of being duped by morality, the context of the entire struggle of good against evil in the light of the hierarchical schematism mentioned above. This leads to the relation between the truth and the good, between reason and the moral, and to the question of whether reason can see the reason for being moral, or, indeed, whether it has to for one to be good or responsible. The good reaches the self at a level prior to lucidity of reason, prior to its capacities of identification. "Knowing, then, 
will take the unsolicited shock of morality for ignorance, foolishness, naivete, slavery" [160]. But the truth of this mind is fixed in the concept of totality for Levinas.

Cohen follows Levinas in tracing the intimate relation between the "interests of epistemology and an ontology of war, war as the ultimate vision of epistemology," [163] where reality takes on the sense of a calculus of force. But, rather, if this epistemology does not have the last word, and if we are not duped by morality, then politics takes on a different meaning, wars would be distinguished between just and unjust, sincerity and not totality would be the ground of the true, and politics would serve or dis-serve the good [165]. And rather than might making right, politics would become "another way of instituting goodness," [165] taking on a quasi messianic role, and peace would underlie struggle and war. This would be a genuine peace, not the peace of might makes right which is basically a dimension of war violating by repressing singularity of oneself and of others. One can approach another in peace only by means of proximity: "Only the radical alterity of the other person has the force - moral force - to obligate and fix the self, the self subject as subjected to the other, as responsibility for the other" [166]. This proximity is the wherein of the constitution of the ultimate and ethical significance of the world. In this context, genuine peace would arise from the proximity of unique singularity in which the significance comes from an ethical breach in the totality, thus transcending the reach of the totalization of war and inserting a non-cognitive moral dimension into philosophical discourse. "Before one knows the good, one does the good," [167] because the demands, obligations, and responsibilities are more important than knowledge and give it significance. The desire for goodness is more desirable than the desire to know. And the resulatant peace is one of pluralism, oriented toward and by the good, where each is responsible for the other, where obligations and responsibilities weigh upon each self for each other and for all others. And this weight is the moral self. "Singularity emerges as a nonsubstitutable responsibility, a moral burden upon which the reality of the whole world depends. Or else there is just war. But war cannot surpass this pacific relation to the other, this sincerity, 
this goodness"[ [168].

James Marsh, in "Rationality and Its Other," attempts to outline a phenomenology of the other in response to postmodern challenges to phenomenology and other forms of western rationality. He points out that if, indeed, modern, western rationality is essentially opposed to the other, inevitably dominating her, excluding her, reducing her to sameness, then a recourse to a post-modern, post-western form of rationality becomes necessary, whether one call that 'genealogy' or 'Denken' or 'negative dialectic' or 'deconstruction,' to name a few of the more common alternatives.' Marsh proposes to test such claims and answer these question by beginning small, doing patient phenomenological descriptions of various forms of rationality as we experience them. Such descriptive accounts liberate us from atomism in perception, and descriptively ground philosophical discourse with evidence, thus avoiding arbitrariness in denying the dichotomy between consciousness and the other.

This phenomenological description of conversation, articulating this essential dimension, shows how such a relation to the other occurs. In this account of a conversation on a point of disagreement, Marsh indicates four positive possibilities in a non-alienated conversation that does justice to otherness: "one person agreeing freely and rationally, both persons moving to a third position, each person modifying their position in relation to the other's, and both persons remaining where they were at the beginning of the conversation" [177]. Each of these possible positions entails a blend of ideality and difference. Even in an uncoerced complete agreement, difference is present, just as in complete disagreement, identity is present. And the negative possibility of coercion or violence are experiences as illegitimate reductions to sameness, as abuse, violating the basic thrust of the conversation toward a "rational, free agreement respectful of difference and listening to the other." This violence is experienced as irrational or at least as inadequately rational, thus requiring a more adequate form of rationality.

Marsh uses the descriptive account to deal with objections to such a priority given to relations to the other in a conversation. He shows how the transcendence to the other is preserved without a 
reduction of the relation descriptively ascertained. Marsh admits his legitimate presupposition of that as true: "eidetic description of the conversation reveals it to be governed by the value of consensus." Such consensus is presupposed by conversation even when some participants are insincere. It is a deficient conversation if that goal or norm is violated. Further, a post-modern or Levinasian critique of phenomenology, to the extent that it is based on a conception of consciousness as purely active, is a caricature, since even Husserl recognized a passivity and receptivity to conscious experience.

We experience the other person as a presence different from that of a stone or an animal, capable of a real and genuine conversation, thus revealing multiple kinds of otherness of experience. Here alone we experience community in unique way with other humans in contrast to the commonness that we experience with things as made of the same stuff, or with animals. This unique communitarian dimension leads us to anticipate responses from the other not anticipated from things or animals. Thus there is a self-revelation of interiority. In the fully reciprocal relation of a conversation, Marsh overcomes the hyperbolical antithesis of interior and exteriority, allowing the conversation to leave in tact both interiority and the transcendence of the other. In this presence of the other we have the basis for consensus "as a regulative ideal in conversation."

Marsh concludes that if such an account of conversation with the other is true, then not only is such a consciousness and conscious rationality open to its other in a first order way, but also, such a phenomenology is open to its other, and thus is not closed off to its other. There is not an essential gap between rationality and its other, but rather, "an essential link and connection. Reason in general and modernist rationality in paricular is being most rational when it is most fully open to its other, least rational when it is most closed." Marsh show that if consciousness as lived is already open as his descriptive account shows, and if such phenomenology can criticize inadequate or dominating ways of relating to the other, "then postmodem rejection or transcendence or overcoming of such rationality seems implausible." We tum now to the last article in this 
collection, one entailing a rather novel and interesting interpretation of Sade in terms of violence.

This article by Colette Michael, "La violence peut-elle être Li'gitime?," focuses on the Marquis de Sade, some of whose works present the epitome of violence, seeking in Sade's own writings for a solution to problems these works pose concerning sexual abuse, torture, and the injustice and abuses against the weak. Michael discusses one such solution of de Sade against physical abuse and violence that are sometimes legal.

Although an author should not be confused with his imaginary works and characters, the Marquis has had attributed to him the black soul [l'ame noire] of his protagonists. Michael, taking into account the point of deconstructive critical theory, that a text can survive the absence of its author and occasional circumstances, notes the coincidence of Sade's recent popularity with the emergence of this new mode of literary criticism. Michael questions the interpretations of Sade's works that, overlooking his contradictions or ignoring other texts, interpret some of his works as antifeminist texts; or, others that, ignoring the intention of the author, the intended audience, the context and the code, consider some of his texts to be pornographic. Michael proposes that the lesson or message of Sade goes a lot further and is different than that, even containing some positive content. She begins by focusing on the much condemned work: Aline et Valcour.

From this story of violence to Aline by her sexually abusive father, Michael draws lessons that are not the usual ones, in this context of Sade's work. First, Aline's virtuous mother, faithful to her marriage vows to the point of defending her husband's incestuous aberrations, ends up being poisoned by him, thus showing that such injustice and violence, even in obedience to marriage vows, does not necessarily lead to happiness or salvation. After the death of her mother, Aline, without her mother's support to marry Valcour, her lover, and against the violence of her father, commits suicide, thus responding with a violence to the violence of unnatural incest. Thus, de Sade does not suggest filial obedience or wifely submission. But such self-suffering is not the only outcome for Sade. He sometimes proposes revolt, as in the three, vastly differing, versions of 
Justine. Justine's virtues of Christian morality and her good actions are rewarded by renewed calamities. After many misfortunes, being raped by someone whom she helped free, tortured, etc., she continues to have faith in the principles of morality which she was taught and which defend the commandments of God and of the Church. "Nothing can make her loose her faith" [187]. But one has to see the more subtle message of Sade presented by Michael: "Quite clearly Sade condemns with one accord the whole of French society of the $18^{\text {th }}$ century, a society which imprisoned him for thirty years, or, if you prefer, a society that condemned without solid proof, innocents such as Justine and Sade" [187]. Faced with the various forms of criminality, the Christian morality of Justine does not function in her favor. Yet she simply opposes violence with her virtue; against crime, she opposes her faith; against malefactors, she opposes her Christian benevolence. These are not valid, and she must revolt, just as Sade must revolt against the French society that imprisoned him. Sade shows the necessity for revolt with his writings that constitute a violence yet unequaled in literature. And, with further analysis of the text, Michael shows precisely how Sade, identifying with Justine, could well be seen to be a masochiste instead of the traditionally understood sadist. Also, one could conclude from the overly passive attitude to one of encouraging crime, and that Justine should revolt.

It would be narrow to interpret Sade only in the antifeminist and pornographic context, since his passages are not too arousing, and since women at times also play the executioner. Thus, there is no absolute in Sade, neither good nor bad. His works, written while imprisoned, and shocking the innocent reader, create a perpetual vengeance against the society that has unjustly condemned him. Against the violence against his own freedom, he has reacted and imagined an unequaled violence in language. "He has in this fact created the perfect crime, a crime that perpetuates itself each time that an offended reader rejects and flees it" [191]. One must clearly in certain cases refuse to bend to abuses, even legal abuses. And Justine exemplifies another less than obvious truth: that, in religious precepts as well as in laws of 
the country, obedience is valid only if these are accepted equally by the "other." "To the question posed by Sade, what to do when faced with violence, "The wise and virtuous Justine, revolted from a system, too unhappy fruit of corruption,' gives this response:

'Evil is useful on earth; and, when God desires it, it is surely a mistake to oppose it.' It is up to us to interpret" [192].

In concluding, it is prudent to realize that, even in a postmodern situation that address violence, there is no end of violence, nor to the discourse on violence. We can, however, make the effort to put violence in its place, and hope thereby in some sense to better the human lot.

Patrick L. Bourgeois

Guest Editor*

-I would like to acknowledge the kind assistance rendered to me by Maureen C. Michaels in editing this volume and my wife, Mary, for her help in the last days. 